\title{
CIVIL RELIGIONDAN MASA DEPAN UMAT BERAGAMA DI INDONESIA: MEMPERTEMUKAN IDEOLOGI KEAGAMAAN DAN IDEOLOGI KEBANGSAAN
}

\author{
Muhammad Aqil Irham \\ Universitas Islam Negeri Raden Intan Lampung \\ mubammadaqilirham@radenintan.ac.id
}

\section{Abstract}

The rise of religious ideology and nationalist movements in Indonesia is still felt today. As a result of all this, there are often truth claims that sometimes end in chaos in the public. So as to mediate all of that an independent and neutral view is needed. The intended view is none other than the existence of civil religion. Civil religion or "religious attitude held by citizens". Civil religion is not at all to shift the position of religion that already exists and is believed by the people in a country. This research includes the type of library research (library research) which will rely on the source of data obtained from library materials both books, articles, journals, newspapers and other literature that support and in accordance with the major themes of this study; among others regarding civil religion, religious ideology, national ideology, and the future of religious communities in Indonesia. The nature of this research is descriptive-qualitative, which seeks to explain various problems and findings carefully and in detail by connecting various data, so that a clear, accurate and factual picture is obtained in accordance with the focus of the study. The right way to bring together religious ideologies and national ideologies is by applying civil religion; where in practice civil religion is to respect differences, strengthen equality, tolerance, free from acts of intimidation, assault and so forth.

\section{Abstrak}

Maraknya gerakan ideologi keagamaan serta ideologi kebangsaan di Indonesia masih terasa sampai saat ini. Akibat dari itu semua, seringkali ada klaim 
kebenaran yang kadangkala berakhir pada kekisruban ditengah publik. Sehingga untuk menengahi itu semua diperlukan suatu pandangan yang independen dan netral. Pandangan yang dimaksud tidak lain adalah adanya civil religion. Civil religion atau "sikap keberagamaan yang dimiliki oleh warga negara". Civil religion sama sekali tidak untuk menggeser posisi agama yang sudah ada dan diyakini oleh masyarakat dalam sebuah negara. Penelitian ini termasuk jenis penelitian kepustakaan (library research) yang akan bertumpu pada sumber data yang diperoleh dari bahan-bahan pustaka baik buku, artikel, jurnal, surat kabar dan literatur-literatur lain yang mendukung dan sesuai dengan tema besar penelitian ini; antara lain mengenai civil religion, ideologi keagamaan, ideologi kebangsaan, dan masa depan umat beragama di Indonesia. Adapun sifat penelitian ini bersifat deskriptif-kualitatif, yaitu berusaha menjelaskan berbagai masalah dan temuan secara cermat dan detail dengan menghubungkan berbagai data, sehingga diperoleh suatu gambaran yang jelas, akurat dan faktual sesuai dengan fokus penelitian. Jalan keluar yang tepat untuk mempertemukan ideologi keagamaan dan ideologi kebangsaan adalah dengan cara menerapkan civil religion; dimana dalam prakteknya civil religion adalah menghargai perbedaan, menguatkan persamaan, toleransi, bebas dari tindakan intimidasi, penyerangan dan lain sebagainya.

Keywords: Civil Religion, Religious Ideology, Ideology

Nationality, Future of Religious People

\section{A. Pendahuluan}

Secara teoritis, hubungan antara agama dan Negara (Politik) pada umumnya dipengaruhi oleh dua dimensi. Pertama, lebih berkaitan dengan dimensi internal agama. Hal ini berarti seberapa jauh sebuah agama dianggap menyediakan cetak biru (blue print) yang mengatur seluruh tata kehidupan, termasuk relasi antara agama dan politik; ataukah sebaliknya, agama dianggap merupakan wilayah private, yang tidak ada sangkut pautnya dengan urusan penyelenggaraan Negara. Kedua, dimensi eksternal yang lebih berkaitan dengan pemahaman penyelenggara Negara terhadap nilainilai agama, bagaimana harus diletakkan. Apakah agama dipahami sebagai wilayah yang tidak ada sangkut pautnya dengan Negara, sebagai yang lazim dianut teori modernisasi yang menggunakan prinsip sekularisasi. ${ }^{1}$ Bahwa agama dan Negara bukan saja tidak ada

${ }^{1}$ Anas Saidi, Menekuk. Agama, Membangun Tabta; Kebijakan Agama Orde Baru, (Jakarta: Desantara Utama. 2004), h. 3. 
sangkut pautnya dengan Negara, tetapi harus dijauhkan dari wilayah public. Bentuk empiriknya, seberapa jauh pemerintah sebagai penyelenggara Negara memberikan ruang pada aktualisasi ideologi keagamaan, baik dalam bentuk partai politik maupun dalam meletakkan hukum agama (syariab) sebagai hukum positif.

Mengenai pola hubungan negara dan agama, para ahli berbeda dalam memberikan kategori pembahasan. Faisal Ismail misalnya, mengemukakan tiga pola hubungan. Pertama, pola hubungan yang ikatannya sama sekali terputus seperti di negara-negara Barat misalnya Inggris, Perancis, Kanada. Kedua, pola hubungan informal seperti Pakistan, Iran, dan Arab Saudi. Ketiga, pola hubungan tidak formal, untuk kasus ini - menurut Ismail - contoh yang tepat adalah Indonesia. ${ }^{2}$ Sementara itu, Parakiri T. Simbolon juga membedakan pola hubungan agama dan negara menjadi Integral simetri (theocracy) dan Integral asimetri. Integral simetri misalnya di Vatikan, Tibet sebelum dikuasai Tiongkok, Iran di bawah Khomeini. Adapun Integral asimetri bisa berupa "agama dalam negara" diantaranya Inggris, Pakistan, Malaysia, Brunei, Filiphina dan Indonesia, dan bisa berupa "negara dalam agama", seperti Iran, Afghanistan dibawah Taliban, dan terakhir adalah Sipil, yang resminya memisahkan agama dan negara, tetapi dalam prakteknya ada satu agama atau lebih yang dominan. ${ }^{3}$ Sedangkan Marzuki Wahid dan Rumadi juga mengemukakan tiga paradigm pemikiran tentang relasi agama dan negara yaitu paradigma integralistik, paradigma simbiotik dan paradigma sekularistik. ${ }^{4}$

Pada sisi lain, agama dan politik juga merupakan dua aspek fundamental dalam setiap kehidupan manusia. Persoalan hubungan antara keduanya telah menjadi bahan pemikiran para ilmuan, filsuf maupun teolog disepanjang sejarah. Hubungan antara agama dan politik selalu menarik untuk dikaji karena keduanya sama-sama memainkan peran penting dalam kehidupan manusia. Politik selalu mempengaruhi agama, sekurang maupun sebanyak agama mempengaruhi politik. Karenanya, usaha untuk memahami

${ }^{2}$ Faisal Ismail, Pilar-Pilar Islam; Pergumulan Kultur dan Struktur (Yogyakarta: LESFI, 2002), h. 64.

3Parakitri T. Simbolon dalam Bentara Kompas, No. 9. Tahun I, Jum'at, 6 Oktober 2000, h. 6.

${ }^{4}$ Marzuki Wahid dan Rumadi, Fiqh Mąhab Negara; Kritik atas Politik Hukum Indonesia (Yogyakarta: Lkis, 2001), h. 22. 
keduanya secara terpisah cenderung akan semakin mengaburkan persoalan, dan bukan memperjelasnya. ${ }^{5}$

Peliknya hubungan antara agama dan politik, terlebih dalam konteks modern, diantaranya diuraikan secara jelas oleh J. Philip Wogemen, yang menyatakan bahwa secara garisbesar terdapat tiga pola umum hubungan politik (negara) dan agama; Pertama, pola teokrasi dimana agama menguasai negara. Kedua, erastianisme yaitu bila yang terjadi adalah sebaliknya yaitu negara mengkooptasi agama. Ketiga, hubungan sejajar antara agama dan negara dalam pemisahan yang unfriendly dan friendly. Pemisahan yang unfriendly antara agama dan negara merupakan hal yang mustahil, karena kehidupan keagamaan selalu memiliki dimensi sosial dan dengan demikian bersentuhan dengan aspek hukum yang menjadi wewenang negara. Karenanya, Wogemen menganggap alternatif terbaik adalah pemisahan yang friendly. ${ }^{6}$

Rumusan teoritis yang memposisikan hubungan antara agama dan negara secara sejajar inilah kemudian yang dikenal dengan wacana tentang agama sipil (civil religion). Menurut John A. Coleman, civil religion merupakan perekat solidaritas sosial maupun politik dari masyarakat, dan hal ini sejalan dengan pemaparan fungsi agama seperti yang dijelaskan Durkheim. Sebab agama maupun politik, dalam diri mereka masing-masing maupun dalam hubungan antara keduanya menyimpan potensi ganda, sebagai perekat maupun sebagai pembelah. Sehingga civil religion diharapkan menjadi penyeimbang untuk mempertemukan keduanya. ${ }^{7}$

Arti civil religion secara harfiah adalah agama sipil (rakyat), akan tetapi jika dilihat secara apa adanya seakan-akan merupakan agama tersendiri - yang berdiri sendiri -. Oleh karenanya civil religion lebih tepat jika diartikan "keberagamaan sipil", karena memang dia tidak memiliki Tuhan, kitab suci, rasul, pendeta, biksu dan sebagainya.

${ }^{5}$ Kiki Muhamad Hakiki, Islam Dan Demokrasi: Pandangan Intelektual Muslim Dan Penerapannya Di Indonesia. Wawasan: Jurnal Ilmiah Agama dan Sosial Budaya 1, 1 (Januari 2016), h. 1-17

'J. Philip Wogemen, Christian Perspective on Politics (Wensminster: John Knox Press, 2000), h. 250-252.

7John A. Coleman, "Civil Religion”, dalam Sociological Analysis, No. 31 (Summer, 1970), h. 69. 
Berbicara tentang civil religion tentu sangat terkait dengan seorang sosiolog modern yang berkebangsaan Amerika, yaitu Robert N. Bellah. Dalam studi kasusnya, Bellah menjadikan Amerika Serikat, sebuah Negara yang pluralis dan demokratis. Dalam pengamatannya yang berkembang di Amerika adalah civil religion, yaitu agama (sekali lagi lebih tepatnya disebut sikap keberagamaan) yang tidak berpihak pada agama-agama tradisional (yaitu agama-agama yang sudah eksis dan berkembang di Amerika) apapun yang dipeluk oleh warga Negara Amerika. Buktinya, menurut Bellah adalah tidak seorang pun Presiden Amerika hingga saat ini tidak seorang presiden Amerika yang menyebut nama tuhan agamanya atau agama tradisional tertentu (seperti Jesus Christ, dan lain-lain). ${ }^{8}$

Oleh karenanya civil religion atau "sikap keberagamaan yang dimiliki oleh warga negara", maka civil religion pun sama sekali tidak untuk menggeser posisi agama yang sudah ada dan diyakini oleh masyarakat dalam sebuah negara, akan tetapi civil religion adalah karena religious mengingat pentingya masyarakat untuk diarahkan kepada "rasa cinta terhadap kewajiban-kewajibannya" baik sebagai warga Negara ataupun sebagai penganut agama, dan civil karena sentimensentimen pembentukannya adalah sosiabilitas, yang tampaknya mereka tidak mungkin menjadi seorang warga Negara yang baik atau seorang manusia yang penuh percaya. ${ }^{9}$

Konsep civil religion yang dikemukan oleh Robert N. Bellah tersebut jika dipahami secara mendalam, sesungguhnya dapat berpengaruh bagi harmonisasi kehidupan umat beragama. Hal tersebut berdasarkan derivasi dari konsep civil religion dan sikap saling menghargai antar masyarakat yang hidup dalam sebuah negara yang

${ }^{8}$ Penjelasan secara tuntas dapat dilihat dalam karangan Robert N. Bellah, Beyond Belief ; Esei-esei tentang Agama di Dunia Modern, terj. Rudy Harisyah Alam (Jakarta: Paramadina. 2000). Dalam buku ini tidak hanya dijelaskan eksistensi agama sipil di Amerika, tetapi juga dijelaskan tentang agama civil yang terdapat di Negaranegara lain seperti Cina, dan Jepang. Bahkan dalam karyanya yang lain dengan judul varieties of civil religion, Bellah juga menguraikan kondisi civil religion di Mexico dan Italia. Lihat juga Robert N. Bellah, The Broken Covenant; American Civil Religion in Time of Trial (Chicago and Londo: The University of Chicago Press, 1992), serta Robert N. Bellah-Phillip E. Hammond, Varietes of Civil Religion, terj. Imam Khori dkk. (Yogyakarta: Irchisod. 2003).

78.

${ }^{9}$ Robert N. Bellah \& Phillip E. Hammond, Varietes of Civil Religion..., h. 
menganut sistem demokrasi, dimana agama yang tumbuh dan berkembang serta mendapat legitimasi dari pemerintah tidak hanya satu agama saja, melainkan berbagai agama. Karena memang civil religion hanya sangat mungkin akan tumbuh pada sebuah negara yang plural sebagaimana yang ditegaskan oleh Robert N. Bellah dan Phillip E. Hammond bahwa 1) kondisi pluralisme keagamaan, yang tidak memungkinkan bagi salah satu agama untuk digunakan oleh seluruh masyarakat sebagai sumber makna general, 2) bagaimanapun juga, masyarakat dihadapkan pada kebutuhan untuk melekatkan sebuah makna dalam aktifitasnya, khususnya ketika aktifitas itu berkaitan dengan individu dari beragam latar belakang keagamaan, 3) diperlukan sebuah sistem makna pengganti dan, jika telah ditemukan, mereka yang aktifitasnya difasilitasi oleh sistem tersebut akan cenderung memujanya. ${ }^{10}$ Hal senanda juga dikemukakan oleh Andrew Shanks bahwa civil religion baru dapat berkembang di dalam sebuah dunia (baca: Negara) yang pluralistik, dimana kewarganegaraan telah berkembang sangat luas. ${ }^{11}$

Memperhatikan apa yang telah di eksplorasi oleh Bellah dan Hammond juga Shanks diatas, nampaknya memang civil religion hanya mungkin dapat dikembangkan dalam suatu Negara dimana terdapat berbagai macam agama yang diakui oleh Negara sebut saja misalnya Indonesia. Dengan kata lain jika sebuah Negara yang berdasar (berafeliasi) pada suatu agama tertentu - seperti Roma, Arab Saudi, Kuwait, Iran -, maka sudah pasti dapat dikatakan civil religion tidak akan dapat dikembangkan.

Dalam kaitan ini kuatnya tarikan antara ideologi keagaman dan ideologi kebangsaan di Indonesia akhir-akhir ini, maka munculnya konsep civil religion setidaknya bisa menjadi obat penawar dari ketegangan tersebut.

Dalam konteks ini, peneliti berasumsi jika sebuah negara yang menganut paham demokrasi, dimana berbagai macam latar belakang yang menjadi "kekayaaan" suatu bangsa harus diakomodir, maka setidaknya civil religion dapat ditawarkan sebab ia dapat membentuk integrasi sosial pada masyarakat luas, sebagaimana yang diklaim oleh

${ }^{10}$ Ibid., h. 186.

${ }^{11}$ Andrew Shanks, Civil Religion, Ali Bahasa Yudi Santoso (Yogyakarta: Jalasutra, 2003), h. 14. 
Durkheim sebagai identitas solidaritas nasional dari agama. Hal ini menunjukkan bahwa terdapat nilai-nilai yang dirujuk dari agamaagama yang ada, kemudian diformulasikan menjadi "pandangan bersama" sebagai titik temu umat beragama. Meskipun tentu saja terdapat perbedaan antara civil religion yang ada di Amerika dengan di Indonesia, mengingat terdapat perbedaan kultur, tradisi, termasuk juga sistem yang dianut oleh kedua negara ini. Dengan begitu maka kearah situlah penelitian ditujukan.

\section{B. Landasan Teori}

Konsep civil religion pada dasarnya juga merupakan salah satu bagian dari konstruksi pembangunan civil society, khususnya dibidang kehidupan keagamaan berkaitan dengan relasi agama dan negara. Studi tentang civil religion dianggap sebagai salah satu usaha menemukan kembali agama dalam wajah modern. Artinya, ada kebutuhan mendasar bagaimana membahasakan agama dalam interpretasi-interpretasi modern sehingga memungkinkan jalannya modernisasi itu sendiri di satu sisi, dan hidupnya agama di sisi lain. Banyak redefinisi yang perlu dilakukan terhadap simbol-simbol dan kelembagaan dalam masyarakat beragama. Masyarakat kontemporer tidak puas lagi menerima hegemoni-hegemoni simbol keagamaan yang membatasi nalar-rasio mereka. ${ }^{12}$

Tidak berlebihan jika dikemukakan bahwa munculnya konsep civil religion merupakan derivasi fakta historisitas yang nampak adanya kehidupan yang serba plural di muka bumi. ${ }^{13}$ Kehidupan yang serba plural tersebut merupakan sesuatu yang alami, atau jika menggunakan bahasa agama bahwa kehidupan tersebut merupakan sunnatullah. Hal tersebut bermakna bahwa manusia memang sengaja diciptakan dalam keadaan yang beranekaragam, oleh karena itu tidak ada pilihan lain bagi manusia selain merespon keanekaragaman tersebut secara arif

${ }^{12}$ M. Murthado, “Agama Sipil:....h. 91.

${ }^{13}$ Menurut Anis Malik Thoha, Tidak terlalu sulit, atau bahkan sangat mudah untuk mencari benang merah yang mengaitkan kelahiraban si jabang bayi "civil religion", atau menemukan hubungan nasab (geneologis) nya, dengan induknya, yakni paham pluralisme agama dan politik. Lihat Anis Malik Thoha, Tren Pluralisme Agama; Tinjauan Kritis (Jakarta: Perspektif, 2007), h. 153. 
dan bijak. Mengabaikan dan mengetepikan keaneragaman sama halnya dengan melawan kodrat yang telah digariskan Tuhan.

Salah satu praktik yang sesungguhnya bisa dilakukan umat manusia adalah membangun konsensus yang bisa diterima semua pihak dengan menggunakan idiom agama sebagai landasan bersama dalam merespon keanekaragaman. Tentu saja penggunaan idiom agama untuk dijadikan konsensus tersebut adalah yang bersifat netral dan indefenden serta bebas dari unsur-unsur diskriminasi.

Karenanya tidak berlebihan jika dikatakan, seandainya umat beragama menginginkan agar supaya tidak terjadi "benturan antar peradaban"14, maka harus secara sukarela mengkonstruk tatanan kehidupan yang lebih apik dengan melakukan apa yang disebut oleh Jean Jacques Rousseau sebagai 'kontrak sosial'. Dengan melakukan kontrak sosial, maka umat beragama akan survive dan rela berkorban membatasi kebebasan invidunya, karena dibalik kebebasan ternyata diseberang sana terdapat pula kebebasan orang lain yang merupakan hak azasi manusia. Hal ini berarti bahwa kebebasan seorang individu akan dibatasi oleh kebebasan seorang individu lain ${ }^{15}$, namun tetap melakukan interaksi.

Menurut Rousseau, dalam melakukan kontrak sosial, seseorang akan kehilangan sebagian kebebasannya. Namun Rousseau menjamin bahwa, karena ia memberikannya kepada keseluruhan masyarakat yang anonym dan abstrak, maka sebenarnya ia tidak menyerahkan kebebasan itu kepada siapapun kecuali kepada dirinya sendiri. Atau dengan melakukan kontrak sosial seseorang akan kehilangan kebebasan alamiahnya - yaitu kebebasan yang ditopang oleh kekuatan individual - namun ia memperoleh kebebasan sipil yaitu kebebasan yang dijamin oleh general will (kehendak umum). ${ }^{16}$

Dalam kaitan ini, sangat menarik apa yang dikemukakan oleh Rousseau bahwa masalah mendasar yang dapat diselesaikan oleh

${ }^{14}$ Istilah ini diadopsi dari Samuel P. Huntington yang mengemukakan teori the clash of civilization (Benturan antar Peradaban).

15Dikalangan para ulama, terkenal adanya ungkapan bijak; Hurriyyat al mar'i mahdudah bi hurriyyat siwa-bu. Lihat Nurcholish Madjid, Cita-Cita Politik. Islam Era Reformasi (Jakarta : Paramadina. 1999), h. 146.

${ }^{16}$ Lihat Jean Jacques Rousseau, Kontrak Sosial, terj. Rahayu Surtiati Hidayat dan Ida Sundari Husen (Jakarta: Dian Rakyat, 2010), khususnya Bab II. 
kontrak sosial adalah "mencari suatu bentuk asosiasi yang mempertahankan dan melindungi pribadi dan milik setiap anggota asosiasi dengan segala kekuatan bersama, dan di dalam asosiasi itu masing-masing yang menyatu dalam kelompok hanya patuh pada dirinya sendiri dan tetap bebas seperti sediakala". Sedangkan 'pasalpasal' dalam kontrak dapat disingkat menjadi satu yaitu alienasi total dari setiap anggota asosiasi berikut semua haknya kepada seluruh masyarakat. $^{17}$

Inti dari teori Kontrak Sosial Rousseau adalah bahwa masingmasing individu melimpahkan segala hak perorangannya kepada komunitas sebagai satu keutuhan. Dengan demikian maka segala hak alamiah, termasuk kebebasan penuh untuk berbuat sekehendak hati yang dimiliki oleh orang-orang dalam kehidupan alamiah itu pindah ke komunitas, atau dalam bahasa politik, pada komunitas sebagai satu keutuhanlah terletak kedaulatan rakyat, dan kedaulatan ini tidak dapat pula dibagi-bagi. ${ }^{18}$ Atau dengan kata lain, mengutip Suseno; kehidupan bersama dengan sendirinya menuntut bahwa kebebasan masing-masing orang dibatasi demi hak dan kebebasan setiap orang lain yang sama besarnya, dan juga oleh tuntutan kehidupan bersama. ${ }^{19}$

Selain teori kontrak sosial yang dikemukakan oleh Rousseau, sebenarnya dapat pula mengkaitkan tema civil religion dengan teori titik temu agama-agama yang diintroduksikan oleh Frithjof Schuon. Schuon menggambarkan sebuah piramida yang dibatasi oleh sebuah garis horizontal. Bagian atas adalah aspek esoterisme, sedangkan bagian bawah adalah aspek eksoterisme. Secara sederhana gambar tersebut dapat dipahami bahwa pada tataran esoterise semua agama bertemua dan bersatu atau semua agama memiliki sesuatu yang

${ }^{17}$ Jean Jacques Rousseau, Kontrak Sosial, terj. Rahayu Surtiati Hidayat dan Ida Sundari Husen (Jakarta : Dian Rakyat. 2010), cet. II, h. 17-18.

${ }^{18}$ Lihat Jean Jacques Rousseau, Kontrak Sosial, alih bahasa Sumardjo (Jakarta : Erlangga. 1986), h. 14. Lihat juga Munawir Sjadzali, Islam dan Tata Negara; Ajaran, Sejarah dan Pemikiran, edisi V (Jakarta : UI Press. 1993), h. 69.

${ }^{19}$ Frans Magnis Suseno, Etika Politik; Prinsip-prinsip Moral Dasar Kenegaraan Modern (Jakarta : Gramedia. 2003), cet. VII, h. 258. Lihat juga Ahmad Suhelmi, Pemikiran Politik Barat; Kajian Sejarab Perkembangan Pemikiran Negara, Masyarakat dan Kekuasaan (Jakarta : Gramedia. 2007), cet. III, h. 251. Serta Firdaus Syam, Pemikiran Politik Barat; Sejarah, Filsafat, Ideologi, dan Pengarubnya Terhadap Dunia ke-3 (Jakarta : Bumi Aksara. 2010), cet. II, h. 154 
disebut dengan the ultimate reality. Sedangkan pada tataran eksoterisme, agama berbeda atau berpisah, dimana masing-masing memiliki cara dan metode dalam hal tata peribadatan atau praktek pengamalan ibadahnya. ${ }^{20}$

Deskripsi Bellah tentang civil religion merupakan salah satu contoh tentang bagaimana ia melakukan pembacaan sosiologis atas fenomena aktual agama. Artinya, ia berhasil membuktikan bahwa perspektif sosiologi agama punya suara, bukan lagi perspektif pinggiran sebagaimana anggapan banyak orang. Bellah mencontohkan praktik civil religion ini dengan mengutip penyebutan "Tuhan" oleh Presiden Amerika John F. Kennedy, dalam pidato pelantikannya sebagai Presiden pada 20 Januari 1961. Konsep Tuhan di situ sama sekali tidak mengacu kepada agama apa pun, karena kalimat itu bisa diterima oleh semua orang. "Jika kita dapat memahami mengapa dia menyebut Tuhan....., maka kita akan banyak memahmi civil religion di Amerika," kata Bellah. ${ }^{21}$

Dalam konteks ini terkait dengan kondisi Indonesia dimana terjadi tarik menarik antara ideologi keagamaan dengan ideologi kebangsaan, harus segera disudahi dengan sama-sama memahami konsep civil religion yang berciri khas Indonesia.

Dengan demikian secara garis besar dapat diungkapkan bahwa dalam penelitian ini yang mengangkat tema besar tentang civil religion, maka akan digunakan beberapa teori yang terkait dengan itu; antara lain teori kontrak sosial yang dikemukakan oleh J.J. Rousseau, serta teori titik temu agama-agama yang diintroduksikan oleh Frithjof Schuon.

\section{Penutup}

1. Istilah civil religion pada mulanya digunakan oleh J.J. Rousseau, kemudian dilanjutkan oleh Robert N. Bellah. Civil religion bukanlah dipahami sebagai bentuk agama dalam pengertian konvensional laiknya Islam, Kristen, Katolik, Hindu, Budha, Konghucu, ataupun yang lainnya yang ada di dunia ini. Dan juga

${ }^{20}$ Lihat Frithjof Schuon, Mencari Titik Temu Agama-Agama, terj. Saafroedin Bahar (Jakarta: Pustaka Firdaus, 1987), h. xi.

${ }^{21}$ Robert N. Bellah, Beyond Belief; .....,h. 239-240. 
bukan merupakan agama baru atau bahkan super agama (super religion) yang akan menggantikan agama-agama konvensional itu. Civil religion adalah justru hendak menjadikan nilai-nilai yang telah ada dan bersemai di dalam agama-agama konvensional tersebut sebagai etika publik. Dengan kata lain, civil religion bersifat artifisial dan melampaui agama-agama yang telah ada, tetapi tentu saja tidak untuk menghapuskan agama konvensional tersebut. Justru yang dikehendaki oleh civil religion adalah revitalisasi nilai-nilai atau etika publik yang disarikan dari agama, seperti mengutamakan kepentingan umum, antiprimordialisme, menghargai hak-hak sesama warga negara, keadilan gender, menghormati keragaman dan pluralitas, atau menjaga kesatuan dan persatuan bangsa. Dengan demikian, civil religion tidak lain adalah merupakan konsensus atau kesepakatan sebuah masyarakat mengenai nilai dan norma yang umum dan harus dihormati oleh semuasecara bersama-sama, dan disadari serta sangat dibutuhkan untuk menjamin kehidupan bersama secara tentram dan terbuka untuk kemajuan masyarakat itu sendiri.

2. Jalan keluar yang tepat untuk mempertemukan ideologi keagamaan dan ideologi kebangsaan adalah dengan cara menerapkan civil religion; dimana dalam prakteknya civil religion adalah menghargai perbedaan, menguatkan persamaan, toleransi, bebas dari tindakan intimidasi, penyerangan dan lain sebagainya. Tujuan yang menjadi orientasi dan acuan bersama adalah orientasi semangat berlomba-lomba dalam kebaikan, menebarkan kasih sayang, menolong sesama dengan rasa kemanusiaan tanpa melihat adanya aneka ragama latarbelakang yang ada seperti, bahasa, budaya, agama, ras, aliran dan lain sebagainya. Dengan sikap itu, mereka mengaktualisasikannya dalam bentuk pengembangan moral universal yang disapih dari simbol-simbol agama tanpa makna serta dapat diterima di ranah publik melalui komunikasi kritis dan suasana dialogis, penuh kejujuran dan keterbukaan.

3. Indonesia yang plural dengan dasar Negara Pancasila tentu sangat terbuka untuk mengembangkan wacana civil religion. Dilihat dari aspek historis, kesadaran para founding fathers akan adanya keanekaragaman yang dimiliki bangsa Indonesia patut diacungi jempol, sebab jauh-jauh sebelumnya mereka sudah memikirkan bagaimana mengakomodasi segala kepentingan yang berasal dari berbagai macam sukubangsa terlebih lagi dari berbagai macam 
agama yang ada. Walaupun pada awalnya terjadi perdebatan hebat antara nasionalis muslim dan nasionalis sekuler, namun pada akhirnya dapat ditemukan kata sepakat bahwa Pancasila-lah yang dijadikan landasan filosofis bagi Republik Indonesia. Sebagai pewaris perjuangan bangsa, maka manusia Indonesia saat ini seharusnya menghargai apa yang telah diperjuangkan, ditetapkan dan disepakati oleh founding fathers tersebut terutama sila pertama dari Pancasila yakni Ketuhanan Yang Maha Esa, sebagai sesuatu yang harus dijunjung tinggi oleh semua elemen bangsa ini. Dengan demikian sesungguhnya dapat dipahami bahwa terdapat relasi atau hubungan antara penerapan civil religion dengan masa depan umat beragama di Indonesia. Artinya dengan civil religion, maka semangat yang diarusutamakan adalah semangat kebersamaan dan juga berpegang teguh pada etos-etos yang dibutuhkan untuk tegaknya kultur demokrasi, seperti mengutamakan kepentingan umum, antiprimordialisme, menghargai hak-hak sesama warga negara, keadilan gender, menghormati keragaman dan pluralisme, menjaga kesatuan dan persatuan bangsa dengan bersama-sama bekerja keras membangun bangsa, dan lain-lain. Ketika semua itu telah terbangun, maka masa depan umat beragama di Indonesia akan menjadi baik, rukun, damai dan harmonis. 


\section{Daftar Pustaka}

Ahmad Suhelmi, Pemikiran Politik Barat; Kajian Sejarah Perkembangan Pemikiran Negara, Masyarakat dan Kekuasaan (Jakarta : Gramedia. 2007)

Anas Saidi, Menekuk, Agama, Membangun Tabta; Kebijakan Agama Orde Baru, (Jakarta: Desantara Utama. 2004)

Andrew Shanks, Civil Religion, Ali Bahasa Yudi Santoso (Yogyakarta: Jalasutra, 2003)

Anis Malik Thoha, Tren Pluralisme Agama; Tinjanan Kritis (Jakarta: Perspektif, 2007)

Faisal Ismail, Pilar-Pilar Islam; Pergumulan Kultur dan Struktur (Yogyakarta: LESFI, 2002)

Firdaus Syam, Pemikiran Politik Barat; Sejarah, Filsafat, Ideologi, dan Pengarubnya Terbadap Dunia ke-3 (Jakarta : Bumi Aksara. 2010)

Frans Magnis Suseno, Etika Politik; Prinsip-prinsip Moral Dasar Kenegaraan Moderm (Jakarta : Gramedia. 2003)

Frithjof Schuon, Mencari Titik Temu Agama-Agama, terj. Saafroedin Bahar (Jakarta: Pustaka Firdaus, 1987)

J. Philip Wogemen, Christian Perspective on Politics (Wensminster: John Knox Press, 2000)

Jacques Rousseau, Kontrak Sosial, terj. Rahayu Surtiati Hidayat dan Ida Sundari Husen (Jakarta: Dian Rakyat, 2010)

John A. Coleman, "Civil Religion”, dalam Sociological Analysis, No. 31 (Summer, 1970)

Kiki Muhamad Hakiki, Islam Dan Demokrasi: Pandangan Intelektual Muslim Dan Penerapannya Di Indonesia. Wawasan: Jurnal Ilmiah Agama dan Sosial Budaya 1, 1 (Januari 2016)

Marzuki Wahid dan Rumadi, Fiqh Mazhab Negara; Kritik atas Politik Hukum Indonesia (Yogyakarta: Lkis, 2001) 
Muhammad Aqil Irham

Nurcholish Madjid, Cita-Cita Politik Islam Era Reformasi (Jakarta : Paramadina. 1999)

Parakitri T. Simbolon dalam Bentara Kompas, No. 9. Tahun I, Jum'at, 6 Oktober 2000

Robert N. Bellah, Beyond Belief; Esei-esei tentang Agama di Dunia Modern, terj. Rudy Harisyah Alam (Jakarta: Paramadina. 2000).

Robert N. Bellah, The Broken Covenant; American Civil Religion in Time of Trial (Chicago and Londo: The University of Chicago Press, 1992)

Robert N. Bellah-Phillip E. Hammond, Varietes of Civil Religion, terj. Imam Khori dkk. (Yogyakarta: Irchisod. 2003). 